\title{
Antagonistic Mechanism of Metabolites Produced by Lactobacillus casei on Lysis of Enterohemorrhagic Escherichia coli
}

\section{OPEN ACCESS}

Edited by:

Miklos Fuzi,

Semmelweis University, Hungary

Reviewed by:

Silvia Yumi Bando,

University of São Paulo, Brazil

Marta Ewa Dec,

University of Life Sciences of Lublin,

Poland

Alessandro Del'Duca,

Instituto Federal do Sudeste de Minas

Gerais, Brazil

*Correspondence: Debabrata Biswas dbiswas@umd.edu

Specialty section:

This article was submitted to

Antimicrobials, Resistance

and Chemotherapy,

a section of the journal

Frontiers in Microbiology

Received: 19 June 2020

Accepted: 26 October 2020

Published: 23 November 2020

Citation:

Aditya A, Peng M, Young A and

Biswas D (2020) Antagonistic Mechanism of Metabolites Produced

by Lactobacillus casei on Lysis

of Enterohemorrhagic Escherichia coli. Front. Microbiol. 11:574422. doi: 10.3389/fmicb.2020.574422

\author{
Arpita Aditya ${ }^{1}$, Mengfei Peng ${ }^{1}$, Alana Young ${ }^{1}$ and Debabrata Biswas ${ }^{1,2,3 *}$ \\ ${ }^{1}$ Department of Animal and Avian Sciences, University of Maryland, College Park, College Park, MD, United States, \\ ${ }^{2}$ Biological Sciences Program, University of Maryland, College Park, College Park, MD, United States, ${ }^{3}$ Centre for Food \\ Safety and Security Systems, University of Maryland, College Park, College Park, MD, United States
}

Enhancing extracellular metabolic byproducts of probiotics is one of the promising strategies to improve overall host health as well as to control enteric infections caused by various foodborne pathogens. However, the underlying mechanism of action of those metabolites and their effective concentrations are yet to be established. In this study, we determined the antibacterial potential of the metabolites in the cell-free culture supernatant (CFCS) collected from wild-type Lactobacillus casei (LC $\mathrm{wt}_{\mathrm{wt}}$ ) and genetically modified LC to overexpress linoleate isomerase ( $\left.L C_{C L A}\right)$. We also evaluated the mechanism of action of CFCSs collected from the culture of $\mathrm{LC}_{\mathrm{wt}}$ in the presence or absence of $0.5 \%$ peanut flour (CFCS ${ }^{w t}$ and CFCS ${ }^{w t+P F}$, respectively) and LC CLA alone (CFCSCLA) against enterohemorrhagic Escherichia coli (EHEC). The metabolites present in CFCS ${ }^{\text {wt }}+\mathrm{PF}$ and CFCS ${ }^{\mathrm{CLA}}$ eliminated EHEC within 24 and $48 \mathrm{~h}$, respectively. Whereas CFCSwt failed to eliminate EHEC but reduced their growth by 6.7 logs $(p<0.05)$ as compared to the control. Significant downregulation of the expression of cell division gene, ftsZ, supported the observed degree of bactericidal and bacteriostatic properties of the collected CFCSs. Upregulation of EHEC genes related to maintaining cell membrane integrity, DNA damage repair, and molecular chaperons indicated an intensive stress condition imposed by the total metabolites present in CFCSs on EHEC growth and cellular structures. A range of deviated morphological features provoked by the metabolites indicated a membrane-targeted action, in general, to compromise the membrane permeability of EHEC. The information obtained from this study may contribute to a more efficient prevention of EHEC related infections.

Keywords: antimicrobial effect, Lactobacillus, metabolites, membrane damage, EHEC, growth inhibition, antibacterial mechanism of action

\section{INTRODUCTION}

Most of the human and animal bacterial infections are treated following the anti-pathogen strategies targeting to either directly eliminate or control growth and proliferation of the pathogen in the host using conventional antibiotics and antimicrobial therapeutics (Callaway et al., 2013). However, the widespread application and/or misuse of antibiotics is raising the concern of 
antibiotic-resistant bacteria, which is limiting the effectiveness of the prophylactic application of the existing antibiotics (Llor and Bjerrum, 2014; Ventola, 2015). Besides, some bacterial infections, including enteric infections with enterohemorrhagic Escherichia coli O157: H7 (EHEC), cannot be treated with traditional synthetic antibiotics because of severe consequences of cytotoxic or adverse effects of the pathogen. For example, antibiotic therapy in EHEC infection can induce the rapid release of Shiga-like toxin (stx) in the gastrointestinal (GI) tract by the death of a vast number of pathogens, which may lead to hemolytic uremic syndrome (HUS) or kidney failure (Cordonnier et al., 2017; Aditya et al., 2019). Further, it also negatively modulates the normal inter-colonic microbial balance which increases the systemic absorption of the toxin (Peng et al., 2015a). Many other therapeutics, such as anti-motility agents, narcotic analgesics, and anti-inflammatory non-steroidal drugs which may alleviate diarrhea, pain, or fever, is also suggested to be avoided in treating EHEC infections because of their observed association with HUS development and lowering the renal blood flow (Cimolai et al., 1992; Murray and Brater, 1993; Bell et al., 1997).

Recent research focusing on the pro-commensal strategy to control foodborne bacterial infections is gaining attention (Callaway et al., 2013). The pro-commensal approach aims to promote the growth of probiotics (e.g., Lactobacillus spp., Bifidobacterium spp., Streptococcus spp., etc.) and suppress the pathogen number or growth in the gut microbial ecosystem (Fuller, 1989; Ouwehand et al., 2002). Adding a specific nutritional component for beneficial microbes, i.e., prebiotic or prebiotic-like dietary products (colloquially termed as "healthfoods" originating from the plant or animal sources, e.g., berry fruits, cocoa, peanut, green tea, etc.), confers selective growth benefits to probiotics and result in the production of a diverse array of their metabolic byproducts (Fuller, 1989; Schrezenmeir and de Vrese, 2001; Reid and McCormick, 2002; Charernjiratragul et al., 2010). In the gut environment, probiotics exert their beneficial potential by competitively excluding the pathogens/opportunistic pathogens, preventing pathogenic adhesion to mucosal surfaces and colonization. The most promising feature of probiotics already established from in vitro and in vivo studies is their antimicrobial activity which is conferred through their metabolic byproducts (Saarela et al., 2000; Mercenier et al., 2008; Kechagia et al., 2013; Ming et al., 2018; Peng et al., 2018). Probiotics alone or in combination with prebiotics (known as a synbiotic strategy) produce many cell-associated and extracellular molecules as well as bioactive metabolites through their normal physiological processes. The formation of these compounds depends on the substrate, population density, particular species and strains of probiotics, and their kinetics (Delgado et al., 2007; Jones et al., 2008). The antibacterial potential of probiotics has been proven to be a concerted effect of these compounds against pathogen growth. Detrimental effects against the growth of both Gram-positive and Gram-negative foodborne pathogens, such as Listeria monocytogenes, Campylobacter jejuni, Enterococcus faecalis, Salmonella enterica, EHEC, Vibrio parahaemolyticus, and $V$. cholerae are observed to be potentially controlled by pro-commensal strategy (Jones et al., 2008;
Mezaini et al., 2009; Charernjiratragul et al., 2010; Nigatu et al., 2015; Ren et al., 2018).

Probiotics have been reported to produce various metabolites, such as flavonoids, glycosyl compounds, steroids, indole, indazole, benzoic acid, gluco-phospholipid, catechol, hydrocinnamic acid, salicylic acid, ferulic acid, caffeic acid, lactic acid, acetic acid, formic acid, linoleic acid, phenyllactic acid, vanillic acid, azelaic acid, hydrocoumaric acid, hydroferulic acid, hydrocaffeic acid, 2,3-butadione, reuterin, acetaldehyde, hydrogen peroxide $\left(\mathrm{H}_{2} \mathrm{O}_{2}\right)$, hydroxyl radical, peptides, or proteins, such as the bacteriocins, and countless derivatives of these compounds (Cleveland et al., 2001; Schnürer and Magnusson, 2005; Broberg et al., 2007; Peng et al., 2015a). Besides foodborne illnesses, many of the lifestyle-based human health complications, e.g., cardiovascular disease, diabetes, obesity, etc. can be prevented and more efficiently treated with a combination of existing drug therapy and healthy dietary choice (Drexler and Institute of Medicine (US), 2010; Ramalingum and Mahomoodally, 2014). Consumption of probiotic bacteria in fermented dairy products or as a supplement has become very popular due to their reported valuable association with lactose intolerance, improved gut health which is linked to the decreased risk of various other complications of the GI tract like irritable bowel disease (IBD), celiac disease, etc. (Salminen et al., 2005; Kechagia et al., 2013; Ramalingum and Mahomoodally, 2014). Similarly, many of the probiotics originated bioactive metabolites, e.g., linoleic acid isomers or conjugated linoleic acid (CLA), have been reported to possess potential anti-carcinogenic, anti-inflammatory, and anti-microbial activities (Banni, 2002; Belury, 2002; Peng and Biswas, 2017). Apart from dietary sources, this essential omega- 6 fatty acid is obtained from microbial biosynthesis of many probiotic species, e.g., Bifidobacterium spp., Lactobacillus acidophilus, L. brevis, L. casei, Corynebacterium spp., etc. (Ogawa et al., 2001; Kishino et al., 2002).

Furthermore, the quantity and quality of metabolites generated by $L$. casei could be improved by peanut flour, and they exhibit more intensive antimicrobial effects towards the growth of common foodborne pathogens (Peng et al., 2015a). However, the mechanism by which these metabolites work against pathogens and their effective concentrations are yet to be elucidated. In this study, we aimed to investigate the underlying mechanism of extracellular metabolites, including CLA, collected from the culture of $L$. casei strains in various conditions against EHEC growth, their cell membrane integrity as well as genomic DNA.

\section{MATERIALS AND METHODS}

\section{Bacterial Strains and Their Growth Conditions}

In this study, Shiga toxin-producing enterohemorrhagic E. coli O157: H7 EDL933 (EHEC EDL933) (ATCC700927) was used as a representative of a foodborne pathogen. This bacterium was grown at $37^{\circ} \mathrm{C}$ overnight on Luria-Bertani (LB) agar or in LB broth (Becton, Dickinson and Co., Sparks, MD, United States) as required under aerobic conditions (Thermo Fisher Scientific 
Inc., Waltham, MA, United States). Two probiotic strains, including wild type Lactobacillus casei $\left(\mathrm{LC}_{\mathrm{wt}}\right)$ (ATCC334) and an engineered linoleate isomerase over-producing L. casei ( $\mathrm{LC}_{\mathrm{CLA}}$ ), previously generated in our laboratory (Peng et al., 2018) were grown at $37^{\circ} \mathrm{C}$ in aerobic conditions on de Man-RogosaSharpe (MRS) agar or in MRS broth (Merck KGaA, Darmstadt, Germany) in a $\mathrm{CO}_{2}$ incubator (Thermo Fisher Scientific Inc., Waltham, MA, United States) as required.

\section{Peanut Flour Preparation and Modulating Metabolites From Probiotics}

Jumbo Virginia in-shell peanuts (Arachis hypogaea) packed and labeled by Royal Oak Peanuts (Drewryville, VA, United States) was purchased from a local vendor, unshelled, and the red skin was removed by hand to collect the raw white kernel parts. Later, they were manually grounded into a fine powder and a $10 \%(\mathrm{w} / \mathrm{v})$ peanut suspension in sterile deionized water was prepared by overnight stirring. Following aseptic techniques, the suspension was sieved by a kitchen fine mesh sieve strainer (LiveFresh, Darwen, United Kingdom) to separate larger peanut fractions from the peanut suspension. The $\mathrm{pH}$ of the sieved peanut suspension was measured and sterilized under UV irradiation for $3 \mathrm{~h}$ and cultured it on LB agar to ensure sterility. Later, this suspension was added in MRS broth to achieve a final concentration of $0.5 \%(\mathrm{v} / \mathrm{v})$ to naturally modulate the metabolites of $\mathrm{LC}_{\mathrm{wt}}$.

\section{Culture Condition of Lactobacillus Strains and Collection of Cell-Free Culture Supernatants (CFCSs)}

Cell-free culture supernatants (CFCSs) were collected from the individual cultures of Lactobacillus strains in MRS broth as described previously by Peng et al. (2015b) with slight modification. Briefly, $0.5 \%(\mathrm{v} / \mathrm{v})$ whole peanut flour suspension was added as supplementation in MRS broth to stimulate the growth of $\mathrm{LC}_{\mathrm{wt}}$ and enhance its metabolite production. Approximately $10^{6}$ colony-forming units $(\mathrm{CFU}) / \mathrm{mL}$ of $\mathrm{LC}_{\mathrm{wt}}$ were inoculated to the fresh MRS broth with or without peanut flour and the metabolites in CFCSs were collected at $48 \mathrm{~h}$ of incubation by centrifuging at $4,000 \times g$ for $20 \mathrm{~min}$, followed by filtration of the supernatant with a sterile syringe filter $(0.2 \mu \mathrm{m}$ pore size) (VWR International, Radnor, PA, United States). $\mathrm{LC}_{\mathrm{CLA}}$ was grown without peanut flour and CFCS was collected following the same procedure. In all conditions, we cultured the L. casei strains $\left(\mathrm{LC}_{\mathrm{wt}}, \mathrm{LC}_{\mathrm{wt}}+\mathrm{PF}\right.$, and $\left.\mathrm{LC}_{\mathrm{CLA}}\right)$ under aerobic condition in $5 \% \mathrm{CO}_{2}$ incubator. The collected CFCSs from $\mathrm{LC}_{\mathrm{wt}}$, $\mathrm{LC}_{\mathrm{wt}}$ in presence of $0.5 \%$ peanut, and $\mathrm{LC}_{\mathrm{CLA}}$ were labeled as $\mathrm{CFCS}^{\mathrm{wt}}, \mathrm{CFCS}^{\mathrm{wt}+\mathrm{PF}}$, and $\mathrm{CFCS}^{\mathrm{CLA}}$, respectively, and preserved at $4^{\circ} \mathrm{C}$ until further use.

\section{Assay of EHEC EDL933 Inhibition With CFCSs Collected From LC wt $_{\text {or }}$ LC CLA $_{\text {. }}$}

The effect of the collected metabolites against EHEC EDL933 growth was determined quantitatively in vitro following the method previously described in triplicate (Peng et al., 2015a; Salaheen et al., 2016; Aditya et al., 2019). Briefly, individual culture tubes containing LB broth and one of the CFCSs $\left(\mathrm{CFCS}^{\mathrm{wt}}\right.$, $\mathrm{CFCS}^{\mathrm{wt}+\mathrm{PF}}$, or $\left.\mathrm{CFCS}^{\mathrm{CLA}}\right)$ in a ratio of $3: 1(\mathrm{v} / \mathrm{v})$ was used as a treatment, where the same ratio of LB and MRS broth was considered as control. For the initial pathogen load, the optical density of EHEC EDL933 was fixed at 0.1 at $600 \mathrm{~nm}\left(\mathrm{OD}_{600}\right)$ by spectrophotometer (PerkinElmer, Waltham, MA, United States) which was further diluted by 100 -fold to achieve a suspension of $\sim 10^{4} \mathrm{CFU} / \mathrm{mL}$. A total of $50 \mu \mathrm{L}$ of the diluted EHEC EDL933 suspension was inoculated to control and treatment tubes, each having a final volume of $5 \mathrm{~mL}$. The number of viable cells in the presence of each type of CFCS was estimated at 4, 8, 12, 24, and $48 \mathrm{~h}$ time points by serial dilution in phosphate-buffered saline (PBS; pH 7.4), followed by plating on LB agar.

\section{Quantitative Assay for Gene Expression of EHEC EDL933 Treated With CFCSs}

For comparing EHEC EDL933 gene expressions in the presence or absence of CFCSs, RNA extraction, and cDNA synthesis were executed in triplicate as previously described (Salaheen et al., 2016; Peng et al., 2018). Using the cDNA (40 ng) as a template, the $\mathrm{q}-\mathrm{PCR}$ reaction mixture was prepared according to PerfeCTa ${ }^{\circledR} \mathrm{SYBR}^{\circledR}$ Green FastMix ${ }^{\circledR}$ protocol (Quanta Biosciences, Beverly, MA, United States) and amplified in an Eco RealTime PCR system (Illumina, San Diego, CA, United States) with $30 \mathrm{~s}$ denaturation at $95^{\circ} \mathrm{C}$, followed by 40 cycles of $95^{\circ} \mathrm{C}$ for $5 \mathrm{~s}, 55^{\circ} \mathrm{C}$ for $15 \mathrm{~s}$, and $72^{\circ} \mathrm{C}$ for $10 \mathrm{~s}$. The relative expression level of the target genes in treatment was calculated by the comparative log fold change. The $C_{\mathrm{t}}$ (cycle threshold) value of target genes in treatment was normalized to the reference gene (Aditya et al., 2019) (all genes used in this study are listed in Table 1) in treatment then the relative expression of the genes was compared between respective treated and untreated conditions (Livak and Schmittgen, 2001).

\section{Fluorescence Microscopy of EHEC EDL933 Treated With CFCSs}

The live/dead cells of EHEC EDL933 treated with CFCSs was determined using the BacLight ${ }^{\text {TM }}$ bacterial viability kit (L7012) (Molecular Probes, Inc., Eugene, OR, United States) following the standard protocol provided by the vendor (Farkas et al., 2017). Briefly, the optical density of the bacterium was fixed at $\left(\mathrm{OD}_{600}\right)$ 0.2 in LB broth which was treated with $25 \%(\mathrm{v} / \mathrm{v})$ of $\mathrm{CFCS}^{\mathrm{wt}}$, $\mathrm{CFCS}^{\mathrm{wt}+\mathrm{PF}}$, and $\mathrm{CFCS}^{\mathrm{CLA}}$ separately. For control, bacterial cells were grown in LB broth mixed with $25 \%$ (v/v) MRS broth. The control and treatments were cultured at $37^{\circ} \mathrm{C}$ under aerobic conditions. At 4,24 , and $48 \mathrm{~h}$ time points, $1 \mathrm{~mL}$ of bacterial suspension from each culture tube was collected, washed three times, and resuspended in PBS. Then the cells were stained with an equal volume of SYTO 9 and propidium iodide (PI) dye. After incubating in the dark for $15 \mathrm{~min}, 5 \mu \mathrm{L}$ of the stained bacterial suspension was taken on a microscope slide and fixed with $0.5 \%(\mathrm{w} / \mathrm{v})$ agarose. A coverslip was swiftly placed on the specimen and visualized under Zeiss AxioObserver fluorescence microscope (Zeiss, White Plains, NY, United States) with $100 \times$ oil immersion objective lens. GFP and DsRed filter sets were used to capture images of the specimens. 
The remaining stained bacterial suspension was analyzed for the fluorescence intensity by a Cytation 5 spectrophotometer (BioTek Instruments, Inc. Winooski, VT, United States) at 530 and $630 \mathrm{~nm}$ for SYTO 9 and PI, respectively. For this step, EHEC EDL933 treated with isopropanol was used as a positive control to confirm cell death.

\section{Scanning Electron Microscopy (SEM) of EHEC EDL933 Cells Treated With CFCSs}

The optical density of EHEC EDL933 culture was measured and adjusted at $0.2\left(\mathrm{OD}_{600}\right)$ in $\mathrm{LB}$ broth and incubated overnight at $37^{\circ} \mathrm{C}$ under aerobic conditions in the presence of either $25 \%$ (v/v) of MRS broth (served as a control), $\mathrm{CFCS}^{\mathrm{wt}}, \mathrm{CFCS}^{\mathrm{wt}+\mathrm{PF}}$, or $\mathrm{CFCS}^{\mathrm{CLA}}$. Both control and CFCSs treated EHEC EDL933 cells were harvested and washed with PBS three times. After that, cells were fixed with $2.5 \%(\mathrm{v} / \mathrm{v})$ glutaraldehyde (Electron Microscopy
Sciences, Hatfield, PA, United States) for $1 \mathrm{~h}$. Five microliters of the fixed bacterial suspension were taken and spread on a polycarbonate membrane filter (pore size $0.2 \mu \mathrm{m}$ ) (Millipore Sigma, Burlington, MA, United States). Then the membranes were washed thrice with PBS followed by dehydration with a series of increasing aqueous ethanol concentrations, each for $15 \min$ [30, 50, 70, 80, and 100\% (v/v)] (Farkas et al., 2017). The membranes were stored overnight under anhydrous calcium sulfate (Peng et al., 2018). The EHEC EDL933 cells on the membrane were gold coated and observed under Hitachi SU-70 FEG scanning electron microscope (Hitachi Ltd., Japan) at an accelerating voltage of $10 \mathrm{kV}$.

\section{DNA Degradation Assay}

From an overnight culture of EHEC EDL933 (inoculum size $\sim 10^{4} \mathrm{CFU} / \mathrm{mL}$ ) in $\mathrm{LB}$ broth, $1 \mathrm{~mL}$ of the bacterial suspension

TABLE 1 | Primers used for RT-qPCR analysis.

\begin{tabular}{|c|c|c|c|}
\hline Function & Gene & Primer sequence $\left(5^{\prime}-3^{\prime}\right)$ & References \\
\hline \multirow[t]{2}{*}{ Housekeeping gene } & 16 S rRNA & F: CGTTACCCGCAGAAGAAGC & Aditya et al. (2019) \\
\hline & & R: GTGGACTACCAGGGTATCTAATCC & \\
\hline \multirow[t]{2}{*}{ Cell division protein } & FtsZ & F: TTGGGTATCCTGACCGTTGC & Used in this study \\
\hline & & R: AGCAGTITGTCGTTCGGGAT & \\
\hline \multirow[t]{12}{*}{ Membrane heat shock proteins } & HtpX & F: GGCAACCCGCTGATCTACTT & Used in this study \\
\hline & & R: AGCGCGGCAATCATIITCTC & \\
\hline & $c p \times P$ & F: TाTCTGCGGTGACAAGACGA & Used in this study \\
\hline & & R: TCAGGCGATAACTGGCATCC & \\
\hline & $p s p A$ & F: ATCCACAGAAACTGGTGCGT & Used in this study \\
\hline & & R: GTITCTIITCTGCCAGCGCA & \\
\hline & $p s p B$ & F: ACCGATCTGGTTATGGCTGC & Used in this study \\
\hline & & R: TTCCAGCGCCTGAATACGTT & \\
\hline & $p s p C$ & F: GTGCGTATCCTGGTGGTGTT & Used in this study \\
\hline & & R: CACCAAAGGCCATGTTGTCC & \\
\hline & $p s p E$ & F: AGTGAAAGAGCGCATTGCCA & Used in this study \\
\hline & & R: CGTGGGTATATCCCATCTCGC & \\
\hline \multirow[t]{8}{*}{ SOS response and DNA replication related genes } & recA & F: CAGGCAGTTGCATTCGCTाT & Used in this study \\
\hline & & R: TCTACGGCGAACTGGTTGAC & \\
\hline & $\operatorname{lexA}$ & F: GGTCGTTGTCGCACGTATTG & Used in this study \\
\hline & & R: CTGCTGACGAAGGTCAACGA & \\
\hline & tus & F: TCCTGGCACAGCTGGAAAAA & Used in this study \\
\hline & & R: ACTTCGCGTTCTGTGGTAGG & \\
\hline & yebG & F: CATAGCGAAAGGGCTTCACG & Used in this study \\
\hline & & R: AGCAAAAAGGAAGCCGATGC & \\
\hline \multirow[t]{12}{*}{ Chaperon proteins } & $i b p A$ & F: CGACGAACAAAAAGAGCGCA & Used in this study \\
\hline & & R: ACCAGGTTAGCACCACGAAC & \\
\hline & $i b p B$ & F: AGCGACGATAACCACTACCG & Used in this study \\
\hline & & R: GCCCTTGATGCAGCCATITT & \\
\hline & $c / p B$ & F: GGCCGAGGAACAGGAATGAA & Used in this study \\
\hline & & R: ATTGGTCAGAACGAAGCGGT & \\
\hline & $\operatorname{grp} E$ & F: GCACAACATCCAGCATCGAC & Used in this study \\
\hline & & R: TGCCGGTGATTGATAGCCTG & \\
\hline & dnaJ & F: TCATGGTTCTGGTCAGGTGC & Used in this study \\
\hline & & R: TGCCGGGATIITAACGGACA & \\
\hline & dnak & F: GAAAGTTGCACTGCAGGACG & Used in this study \\
\hline & & R: GGTTAACGTCTITACGCGGC & \\
\hline
\end{tabular}


was harvested and quickly spinned to collect the pellet. Genomic DNA was extracted from this pellet with Trizol $^{\mathrm{TM}}$ reagent (Invitrogen, Waltham, MA, United States) according to the Trizol Reagent (DNA isolation) user guide (Chomczynski and Sacchi, 1987). The extracted genomic DNA was treated with CFCSs to investigate their DNA damaging potential (Brudzynski et al., 2012). DNA (90 $\mu \mathrm{g} / \mathrm{mL})$ was mixed with CFCSs in a ratio of $3: 1$ and incubated at $37^{\circ} \mathrm{C}$ for $4 \mathrm{~h}$. DNA treated with $\mathrm{LB} / \mathrm{MRS}$ broth in the same ratio considered for the control. After the treatment, $1 \mu \mathrm{L}$ of the $5 \times$ loading dye was added, and the mixture was loaded onto a $1 \%$ agarose gel. Gel electrophoresis was performed according to a protocol described previously (Brudzynski et al., 2012).

\section{Statistical Analysis}

SAS 9.2 software (SAS Institution Inc., Cary, NC, United States) was used to determine the statistical significance. The oneway analysis of variance (ANOVA) followed by Dunnet test was applied to determine significant differences of EHEC EDL933 growth and gene expression levels between control and treatment based on a significance level of 0.05 .

\section{RESULTS}

\section{Growth Inhibitory Effect of CFCSs on EHEC EDL933}

Quantitative assessment of the antagonistic effect of the metabolites collected in $\mathrm{CFCS}^{\mathrm{wt}}, \mathrm{CFCS}^{\mathrm{wt}+\mathrm{PF}}$, and $\mathrm{CFCS}^{\mathrm{CLA}}$ exhibited statistically significant bactericidal property against EHEC EDL933 as compared to the control (Figure 1). Metabolites of $\mathrm{LC}_{\mathrm{wt}}$ which was enhanced by peanut flour supplement $\left(\mathrm{CFCS}^{\mathrm{wt}+\mathrm{PF}}\right.$ ) exhibited the strongest inhibitory potential by eliminating EHEC EDL933 growth within $24 \mathrm{~h}$, whereas metabolites collected from $\mathrm{LC}_{\mathrm{wt}}$ without the supplement $\left(\mathrm{CFCS}^{\mathrm{wt}}\right.$ ) could not eradicate the pathogen even after $48 \mathrm{~h}$ of the treatment. However, a continuous bacteriostatic effect was observed on $\mathrm{CFCS}^{\mathrm{wt}}$, which reduced the growth of pathogen by $6.7 \operatorname{logs}(p<0.05)$ as compared to the control at $48 \mathrm{~h}$. The CFCS collected from LC $\mathrm{CLA}$ (CFCS ${ }^{\mathrm{CLA}}$ ) which contained more CLA than the other two CFCSs (CFCS $^{\text {wt }}$ and $\mathrm{CFCS}^{\mathrm{wt}+\mathrm{PF}}$ ) exhibited a stronger bactericidal effect than CFCS $^{\text {wt }}$ against EHEC EDL933 by eradicating its growth within $48 \mathrm{~h}$ (Figure 1).

The antagonistic effect of the CFCSs on the growth of EHEC EDL933 was also observed at both lower and higher concentrations. A lower concentration of all the collected CFCSs (e.g., $10 \% \mathrm{v} / \mathrm{v}$ ) exerted a bacteriostatic effect on the pathogen which was attenuated after $4-8 \mathrm{~h}$ depending on the Lactobacillus strains and the growth condition specifically the presence or absence of peanut flour as a growth supplement. Whereas a higher concentration (e.g., $\geq 50 \% \mathrm{v} / \mathrm{v}$ ) of CFCSs regardless of the cultural conditions eradicated EHEC EDL933 within $12 \mathrm{~h}$ as compared to the negative control (without CFCS, data not shown).

\section{Alteration of EHEC EDL933 Gene Expression Indicates Adverse Growth Environment}

The relative expression of several critical genes of EHEC EDL933 cells, specifically the genes involved in cellular structure and cell-

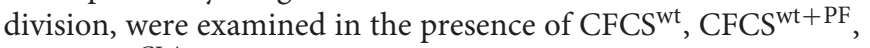
and CFCS $^{C L A}$ (Figure 2). The most crucial gene for bacterial cell division, $f t s Z$ which binds with the Z-ring to facilitate cell division was significantly downregulated (Figure 2A) in the presence of all of three CFCSs but the suppressive effect by CFCS ${ }^{\text {CLA }}$ was more intense than the other two CFCSs $\left(\mathrm{CFCS}^{\mathrm{wt}}\right.$ and $\mathrm{CFCS}^{\mathrm{wt}+\mathrm{PF}}$ ), indicating the presence of metabolites produced by LCCLA is important but their concentration, possibly CLA, is critical in intensive inhibition of growth and cell division of EHEC EDL933.

On the other hand, genes associated to maintain membrane structure ( $h t p X, c p x P, p s p A, p s p B, p s p C$, and $p s p E)$ of EHEC EDL933 were upregulated due to the treatment with CFCSs collected from LC cultures (Figure 2B). We found that expression of these genes was upregulated at various folds ranging from 2 to 8.2 which could be linked to the notion of membrane targeting activity of the metabolites. We also evaluated the expression of some genes known as molecular chaperones $(i b p A, i b p B, \operatorname{clp} B$, $\operatorname{grp} E$, dnaJ, and $d n a K)$ which are expressed in stress as well as in non-stressed conditions. In this study, CFCS ${ }^{w t+P F}$ and CFCS $^{\text {CLA }}$ upregulated the expression of all chaperon genes that were tested, however in the presence of CFCS ${ }^{\mathrm{wt}}, \mathrm{clpB}$ and $d n a K$ genes were found to be downregulated, indicating that the effect is attributed to the variation in CFCS composition in terms of concentration (Figure 2C). The upregulation of the DNA replication and SOS response-related genes ( $\operatorname{rec} A$, lexA, tus, and yebG) indicated that the CFCSs regardless of the source might also have a DNA damaging activity (Figure 2D) arising from the metabolites.

\section{Membrane Integrity of EHEC EDL933 Is Compromised by CFCSs}

In membrane integrity assay, we observed that the extracellular metabolic byproducts of $L$. casei strain present in $\mathrm{CFCS}^{\mathrm{wt}}$, $\mathrm{CFCS}^{\mathrm{wt}+\mathrm{PF}}$, and $\mathrm{CFCS}^{\mathrm{CLA}}$ influenced the normal cell membrane permeability of EHEC EDL933 cells by directly disrupting the membrane integrity (Figure 3). To compare the membrane damage, the CFCS treated and non-treated EHEC EDL933 cells were visualized after staining with fluorescent nucleic acid dyes SYTO 9 and PI. In general, green fluorescence is observed from a population when stained with SYTO 9, since the dye stains the DNA of both bacteria with the intact and damaged membrane. On the other hand, PI can penetrate bacterial cells only when the normal cell membrane integrity is compromised. When costained the red fluorescence overrides the green one because of their stronger affinity to DNA than SYTO 9. We observed a significant progression in cell membrane disruption by all treatments over the $48 \mathrm{~h}$ period (Figures 3A,B), which was reflected by the progressive abundance of red fluorescence as compared to the control. Fluorescent micrographs (Figure 3A) of the CFCSs-treated cells showed an increasing number of red fluorescent cells with the progression of treatment time 


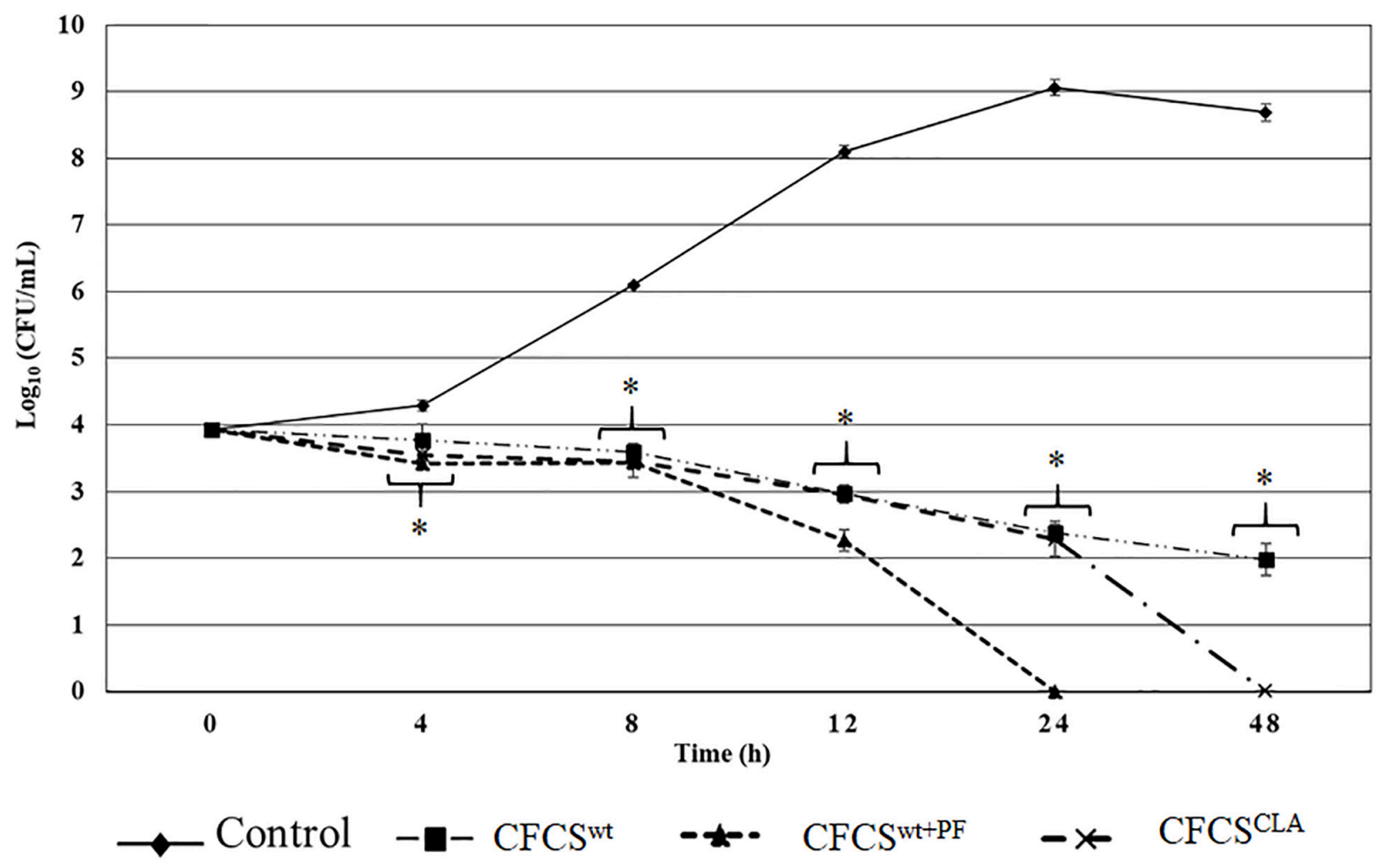

FIGURE 1 | Antagnostic effect of crude metabolites (CFCS ${ }^{\text {wt }}$, CFCS ${ }^{\text {wt }+P F}$, and CFCSCLA) against the growth of EHEC EDL933 over $48 \mathrm{~h}$ time. The bars represent the average \pm standard deviation among replicates and the asterisks $\left(^{*}\right)$ indicate a significant difference between control and treatment $(p<0.05)$.

A
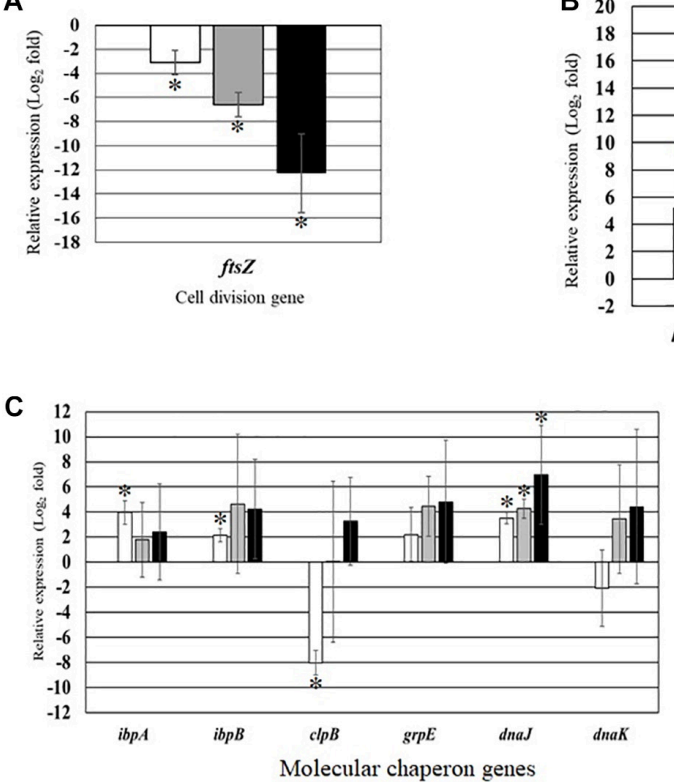

CFCS $^{\mathrm{wt}} \square$ CFCS $^{\mathrm{wt}+\mathrm{PF}}$

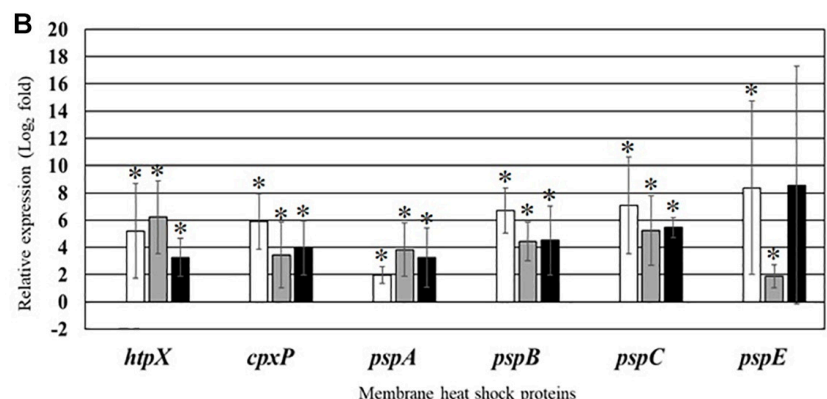

D

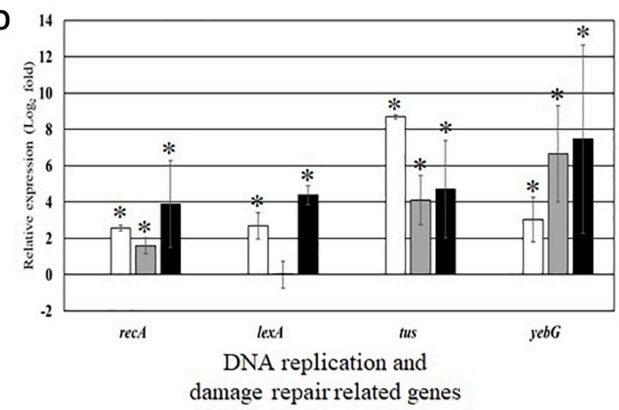

CFCSCLA

FIGURE 2 | Relative expression of genes related to EHEC EDL933 cell division (A), membrane heat shock proteins (B), various molecular chaperon genes (C), and DNA replication and damage repair-related genes (D). The bars represent relative fold-change between control and individual treatment. The error bars are showing the \pm standard deviation among replicates, and the asterisks $\left(^{*}\right)$ indicate a significant difference between control and treatment $(p<0.05)$. 


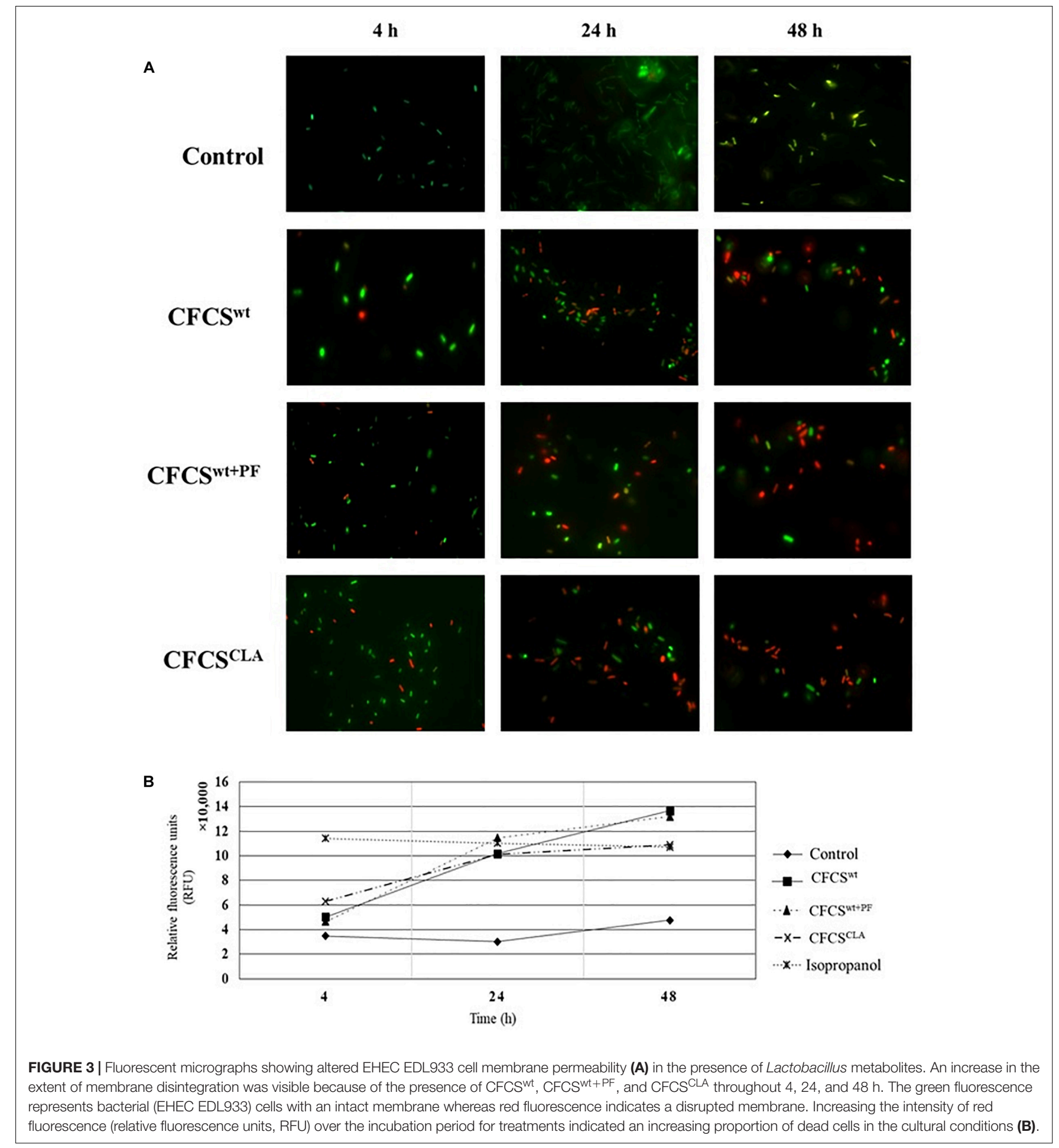

(up to $48 \mathrm{~h}$ ). A discernable variation in the number of red fluorescent cells was observed among the treatments. A similar proportion of damaged cells were observed from $\mathrm{CFCS}^{\mathrm{wt}+\mathrm{PF}}$ and $\mathrm{CFCS}^{\mathrm{CLA}}$ at $48 \mathrm{~h}$ while $\mathrm{CFCS}^{\mathrm{wt}}$ had comparatively less damaged cells at the same time point. However, a significant number of green fluorescent EHEC EDL933 cells were detected under the microscope while the growth inhibition assay showed complete elimination of the pathogen. These findings can be related to the diverse mechanism of growth-inhibitory action of CFCSs besides bacterial cell membrane disruption that arises due to the diversity and concentration of metabolites present in CFCSs. 

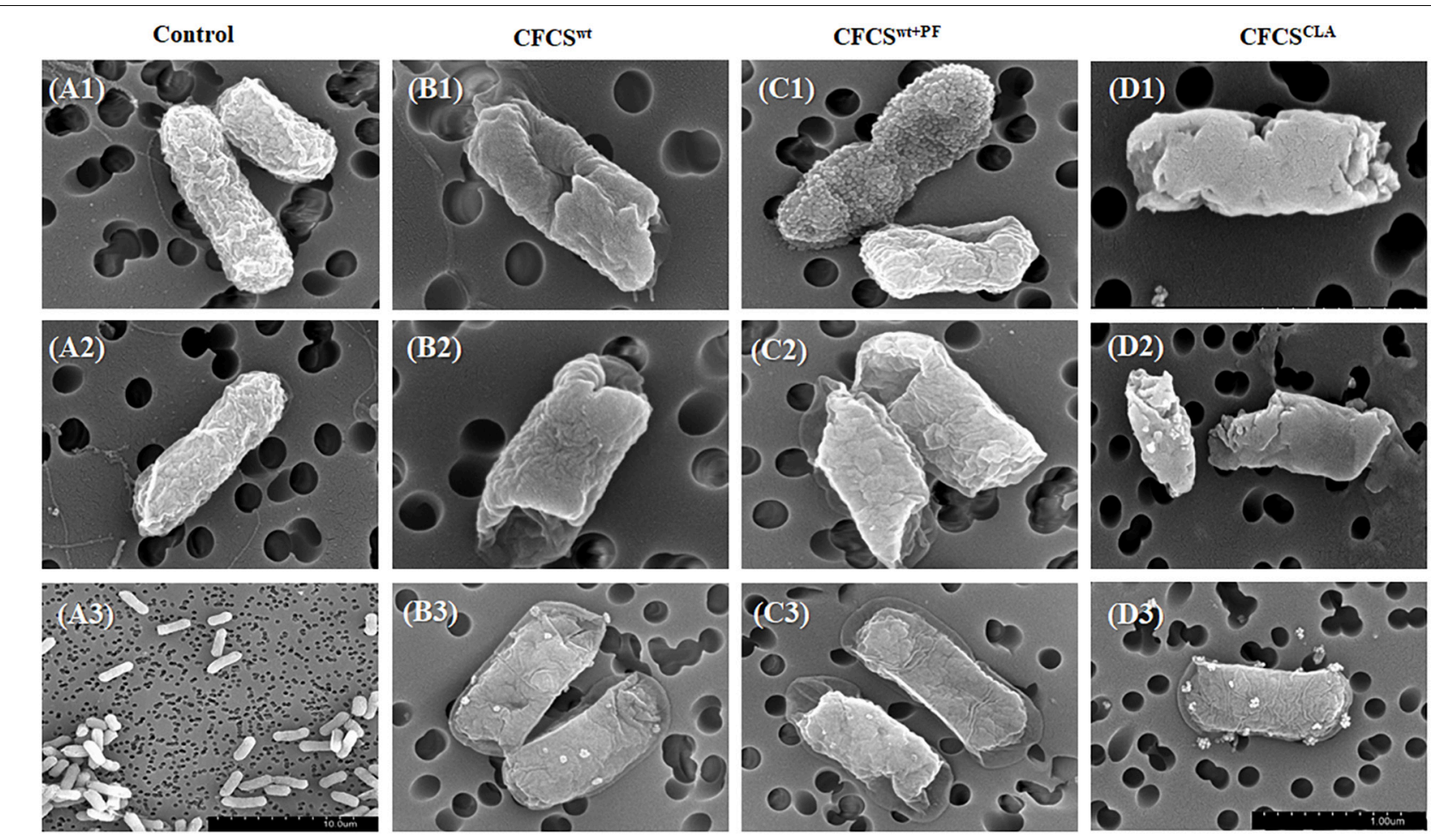

FIGURE 4 | Scanning electron micrographs showing the effect of metabolites in CFCSs on the EHEC EDL933 cell surface after overnight (18 h) incubation. No membrane disruption was visible on the control group (A1-A3), whereas dents were apparent at the ends of the cells (B1, B2, C2). Apart from the dents, bleb-like structures were also visible (C1), while a crumpled and blistery surface was also observed (D1-D3). In some cells, the plasma membrane was displaced from the cell wall $(\mathbf{B} 3, \mathbf{C} 3)$.

The spectrophotometric observation (Figure 3B) of the CFCS treated EHEC EDL933 cells showed a growing proportion of membrane damaged cells which were reflected by the increasing red fluorescence (at $630 \mathrm{~nm}$ wavelength). For this assay, EHEC EDL933 cells treated with 70\% isopropanol was used as a positive control for bacterial membrane damage as isopropanol lyse bacterial cells by dissolving the membrane. The fluorescence from the isopropanol treated EHEC EDL933 cells remained static throughout the experiment because of their rapid mode of action. On the other hand, red fluorescence of EHEC EDL933 cells cultured without CFCSs was significantly lower than other treatments that exactly coincided with the fluorescent microscopy and growth inhibition experiment.

\section{Morphological Deviation of EHEC EDL933 Membrane Treated With CFCSs}

The effects of the CFCSs collected from different cultural conditions, i.e., $\mathrm{CFCS}^{\mathrm{wt}}$, $\mathrm{CFCS}{ }^{\mathrm{wt}+\mathrm{PF}}$, and $\mathrm{CFCS}^{\mathrm{CLA}}$ on EHEC EDL933 membrane showed significant divergence (Figure 4). The morphology of CFCS-treated EHEC EDL933 cells was visualized to compare the effect of metabolites and their concentration using SEM. The electron micrographs of overnight $(18 \mathrm{~h})$ CFCSs-treated cells showed distinct morphological attributes of the membrane as compared to the control. Untreated EHEC EDL933 cells' morphology was undamaged (Figures 4A1-A3), while all the CFCS-treated EHEC EDL933 cells exhibited a diverse array of membrane disruption and deviation from the normal structure. The metabolites present in $\mathrm{CFCS}^{\mathrm{wt}}$ disrupted both outer and inner membranes (IMs) from random directions which made a hollow opening on the pathogen (Figures $4 \mathbf{B 1} \mathbf{B} \mathbf{B}$ ). In addition to the membrane disruption, a bleb-like structure was observed uniquely when the pathogen was treated with CFCS ${ }^{\mathrm{wt}+\mathrm{PF}}$ (Figure 4C1). Whereas, some EHEC EDL933 cells exhibited a crinkly appearance with a smooth surface in the presence of $\mathrm{CFCS}^{\mathrm{CLA}}$ (Figures 4D1,D2). This particular appearance was also uniquely seen in CFCS ${ }^{\mathrm{CLA}}$ treated cells which might be the concerted effect of CLA along with other metabolites. Dislocation of the plasma membrane from the bacterial cell wall was observed in all three types of CFCS treated EHEC EDL933 cells (Figures 4B3,C3,D3). Although no obvious disruption of the outer membrane was apparent in these cells, the cytoplasmic content was seemed to be released possibly through a porous opening on the displaced membranes.

\section{DNA Degradation by CFCSs}

The effect of CFCSs on EHEC EDL933 genomic DNA was investigated by agarose gel electrophoresis. All the collected CFCSs (CFCS ${ }^{\mathrm{wt}}$, CFCS ${ }^{\mathrm{wt}+\mathrm{PF}}$, and CFCS ${ }^{\mathrm{CLA}}$ ) were found to be destructive to the DNA of EHEC EDL933 within the $4 \mathrm{~h}$ of treatment (Figure 5). However, an interesting fact was observed from $\mathrm{CFCS}^{\mathrm{wt}+\mathrm{PF}}$ since there was no visible band in the lane 


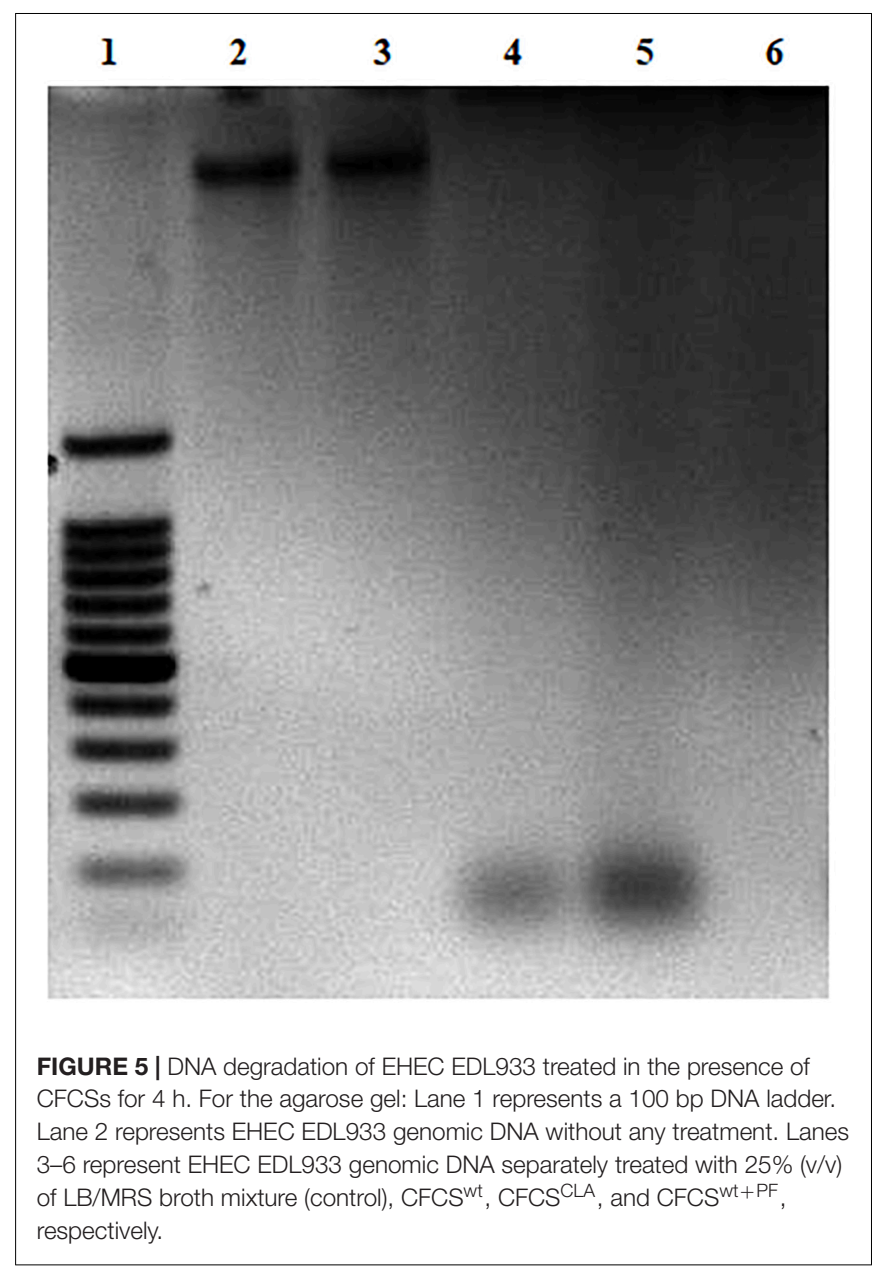

(Figure 5, lane 6) while $\mathrm{CFCS}^{\mathrm{wt}}$ and $\mathrm{CFCS}^{\mathrm{CLA}}$ lanes showed bands at around $100 \mathrm{bp}$. This might be connected to the presence of metabolites that are coming from the peanut flour.

This study was also performed with $\mathrm{pH}$ adjusted CFCSs. The original $\mathrm{pH}$ of the $\mathrm{CFCS}^{\mathrm{wt}}, \mathrm{CFCS}^{\mathrm{wt}+\mathrm{PF}}$, and $\mathrm{CFCS}^{\mathrm{CLA}}$ were 3.71, 3.48 and 3.75, respectively. After adjusting the $\mathrm{pH}$ to 5.43 [the $\mathrm{pH}$ of 3:1 (v/v) mixture of LB and MRS broth], the same effect was recorded as of $\mathrm{pH}$ non-adjusted CFCSs (data not shown). Therefore, this observation indicated that the destruction of DNA was not the effect of acidic $\mathrm{pH}$ rather the concentration of metabolites present in the CFCSs.

\section{DISCUSSION}

The growth of probiotics and their production ability of extracellular metabolites can be enhanced by supplementing prebiotics which is indigestible by the hosts, such as inulin, fructooligosaccharides, pectic oligosaccharides, oligofructose, and polyphenols in both culture condition and feed/food (Rurangwa et al., 2009; Pranckutè et al., 2016). A similar effect has been observed by supplementing prebiotic-like foods known as functional foods, such as peanut, cocoa, or berry fruits (Peng et al., 2015a; Salaheen et al., 2016; Tabashsum et al.,
2018). The nourishing effects of functional foods on human health are associated with the content and concentration of fatty acids, plant-based protein, vitamins, minerals, fiber, antioxidants, sterols, flavonoids, and phenolics (Grosso et al., 2015; Arya et al., 2016; Lamuel-Raventos and Onge, 2017). However, sometimes some of these components may be linked to undesirable conditions, e.g., $\alpha$-arachin protein present in peanut white kernel is thought to be the cause of peanut allergy (Johns and Jones, 1916; Barnett et al., 1983). Besides, fungal infestation, e.g., Aspergillus flavus on grainy functional foods is linked to aflatoxin mediated carcinogenesis (Achar et al., 2009). Considering these adverse effects, cost, availability, and persistent applicability all prebiotics cannot always stimulate the growth and metabolite production of probiotics for hosts. Hence, engineered probiotics capable of producing critical metabolites without the presence of prebiotic components are an alternative option (Peng et al., 2018). Further, such type of modified probiotic strains could be more effective in the fermentation of dairy products and vegetables. In this study, we qualitatively compared the specific effects arising from the metabolites of a probiotic bacterium when it grows alone, in presence of a prebiotic-like supplement, and aimed to achieve a similar beneficial effect by genetically engineering a probiotic strain through overproducing one of the bioactive metabolites, CLA.

In agreement with Peng et al. (2018) reported previously, we also observed a gradual decline in the growth of EHEC exerted by all collected CFCSs from $L$. casei strains in a time-dependent manner (Peng et al., 2015a, 2018). However, $\mathrm{CFCS}^{\mathrm{wt}+\mathrm{PF}}$, collected from the $L$. casei in the presence of peanut flour, exhibited a stronger inhibitory effect than CFCS $^{\text {wt }}$ as well as CFCS ${ }^{\text {CLA }}$, as expected. By genetic modification of L. casei, we could increase the conversion of CLA only 21 folds (Peng et al., 2018) while in the presence of peanut flour $(0.5 \%)$ they might have produced more CLA and other metabolites as well. Hence, CFCS ${ }^{\text {CLA }}$ which contained a higher amount of CLA inhibited the growth of EHEC more efficiently than CFCS ${ }^{\text {wt }}$ which was collected from wild-type L. casei without the peanut flour supplement. Lamuel-Raventos and Onge (2017) reported that nutritionally indigestible components of peanuts like polymerized polysaccharides and polyphenols are enzymatically converted by gut microbes into a diverse array of metabolic byproducts encompassing organic acids, fatty acids, and $\mathrm{H}_{2} \mathrm{O}_{2}$, etc. (Lamuel-Raventos and Onge, 2017) that might have conferred the relatively rapid antagonistic effect of $\mathrm{CFCS}^{\mathrm{wt}}+\mathrm{PF}$ against EHEC growth in our study.

Previously, we also reported that CFCS ${ }^{\text {CLA }}$ impaired physicochemical properties of bacterial pathogens such as autoaggregation, surface hydrophobicity, and biofilm formation of several enteric bacterial pathogens more efficiently than CFCS ${ }^{w t}$ (Vu et al., 2009; Peng et al., 2018; Tabashsum et al., 2018). As the physicochemical properties play a major role in pathogenic bacterial adherence to host cells, secretion of effector proteins, and initiate colonization (Sorroche et al., 2012; Cordonnier et al., 2017; Aditya et al., 2019), we also compared the expression of genes which are involved in such physicochemical properties and secretion of proteins in the presence of CFCSs collected from $\mathrm{LC}_{\mathrm{wt}}$ and $\mathrm{LC}_{\mathrm{CLA}}$. Major virulence genes involved in EHEC 
Type-III secretion system (T3SS), i.e., eaeA, espA espB, espD, tir, and ler are downregulated presumably by the polyunsaturated fatty acid components of CFCSs (Cardenal-Muñoz and RamosMorales, 2011; Peng and Biswas, 2017; Peng et al., 2018). Altered physicochemical properties and virulence gene expression of EHEC are concurred with its reduced adherence to host intestinal epithelial cells. A paucity of receptor-like molecules on the host cell surface is one of the reasons for reduced adherence since the receptors are already settled with the metabolites present in CFCSs (Bernet et al., 1994; Matsuo et al., 2012; Peng et al., 2015b).

It is already explicitly established that the components of CFCSs create an adverse condition that induces the pathogen to adaptively regulate its genes in response to such stressful conditions for their survival (Wall et al., 2004; Seshasayee et al., 2009). We observed a significant downregulation of fts $Z$, the key regulator of EHEC cell division, which coincides with our observed bacteriostatic effect of CFCSs regardless of the source in the first $5 \mathrm{~h}$ of treatment. In an unfavorable growth environment, such as nutrients insufficiency, adverse $\mathrm{pH}$, and presence of growth inhibitory compounds bacteria usually delay their proliferation due to the inhibition of septal ring ( $\mathrm{Z}$ ring) proteins specifically FtsZ or DnaA or disruption of other factors involved in Z-ring formation (Arends and Weiss, 2004; Jonas, 2014). When the Z-ring is unable to form septa, the cells continue to grow like long aseptate filaments which may not form colonies upon plating (Addinall et al., 1997; Vicente et al., 2006). In this study, a stronger suppression on $\mathrm{fts} Z$ gene was observed when the EHEC EDL933 cells were treated with $\mathrm{CFCS}^{\mathrm{CLA}}$ which might be correlated to the higher concentration of metabolites including CLA.

In a stressful environment, bacterial cells produce defective and misfolded membrane proteins much higher than they would produce in a favorable growth condition. To retain membrane integrity, the bacterial cells need to correct or destroy the misfolded proteins (Sakoh et al., 2005). In our study, we observed an overexpression of $h t p X$ and $c p x P$ genes which are involved in the quality control of membrane proteins of EHEC in the presence of CFCSs. We also observed an upregulation of genes that are involved in phage shock protein operon ( $p s p A, p s p B$, $p s p C$, and $p s p E)$. Yoshitani et al. (2019) found that $h t p X$ along with $\mathrm{ftsH}$ lyse the abnormal IM proteins of EHEC (Yoshitani et al., 2019). Besides, Shimohata et al. (2002) reported that the accumulation of misfolded proteins in the IM may occur due to the inefficiency or loss of $h t p X$ or $f t s H$ which further activates Cpx stress response proteins located in periplasmic space (Shimohata et al., 2002). The Psp proteins are thought to be a part of the interrelated stress response system to manage the membrane. An increased permeability of IM caused by the mislocalization of secretin proteins activates the psp-system. Secretins are components of the export system essential for virulence, biofilm formation, and antibiotic resistance of EHEC (Joly et al., 2010; Srivastava et al., 2017). Under non-stress conditions, Psp proteins (except PspA) are almost undetectable where PspA along with HtpX and DnaK represses the psp-system (Elderkin et al., 2002). When a stress signal is received by IM-bound PspB and PspC and transferred to PspA thereby downregulating it and increasing other Psp proteins (Weiner et al., 1991; Jovanovic et al., 2006; Nonaka et al., 2006). In this study, we observed an upregulation in all $p s p(p s p A, p s p B$, and $p s p C)$ genes, while PspA was expected to be downregulated in CFCSs-induced stress conditions. However, researchers also found that when any gene is only expressed under adaptive control (in this study $p s p B$ and $p s p C$ ), there might be a delay to produce enough protein to adjust to the situation and during such time could lead to death or abnormal cellular morphology (Brissette et al., 1990; Price et al., 2013).

To evaluate the effect of CFCSs on the EHEC EDL933 cell membrane, we studied the EHEC membrane intactness and found evidence of membrane disruption caused by metabolites present in CFCSs. Our fluorescent microscopic and spectrophotometric data indicated that during the earlier hours of treatment, membrane disruption was less which was apparent by the lower signal intensity of red-fluorophore, PI. The PI is a widely used stain to detect dead cells; this dye can only penetrate cells with a disrupted membrane, intercalates to DNA irrespective of base-composition, or degradation with one dye molecule binding per 4-5 base pairs (Waring, 1965; Stocks, 2004). In our study, the proportion of membrane damaged cells increased with longer CFCS treatment duration, albeit there was a considerable proportion of green-fluorescent signal from SYTO 9 dye indicating the presence of bacteria with intact membrane. This variance of our fluorescent microscopic observation from the time-dependent growth reduction of EHEC was understood after the EHEC membrane morphology analysis by SEM. The electron micrographs revealed several membrane altering effects of CFCSs on EHEC. The control cells displayed a normal intact surface whereas the treatments exhibited a multitude of the wrinkled-irregular membrane, bleb-like surface, deep craters on both sides of the cell, shrinkage of the IM, blisters, etc. The "bleby" surface morphology was observed uniquely in $\mathrm{CFCS}^{\mathrm{wt}+\mathrm{PF}}$ treatment. This type of structure is formed at places on the outer membrane due to the deficiency of lysine, which can result in the detachment of the outer membrane from the underlying layer of peptidoglycan (Chatterjee and Chaudhuri, 2012). Lysine is an essential amino acid for humans which is present in peanuts and is also required for bacterial membrane protein synthesis (Gillner et al., 2013). Peanut originated components later metabolized by $L$. casei in our study have presumptively interfered with the EHEC lysine biosynthetic pathway hence resulted in the bleb-like appearance. In all treatment, no obvious disruption was apparent in some cells other than a detachment of the IM from the outer membrane, which explains the dissimilarity of our fluorescent microscopic and EHEC EDL933 growth reduction observation.

Heat shock proteins induced under stress usually act as protease (e.g., HtpX, Lon, and DegP), chaperons (e.g., ClpB, DnaJ, and DnaK), or chaperon helper (e.g., IbpA and IbpB) (Lewis, 2019). We observed the expression of some SOS pathway and chaperon related genes of EHEC EDL933 in the presence of collected CFCSs. LexA and RecA are two major proteins of SOS response in EHEC EDL933 where the cell's response to DNA damage is mediated by expression of about 40 genes of SOS regulon by LexA repressor and RecA (Campoy et al., 2005). In normal growth condition, LexA represses/limit the expression 
of SOS genes (Friedberg et al., 2005). Upon encountering DNA damage stimuli, $\operatorname{Rec} A$ becomes activated which facilitates the autolysis of LexA thereby initiating the expression of SOS genes that are involved in DNA damage tolerance, DNA repair, and delay of the cell cycle (Kreuzer, 2013). In our study, we observed a parallel overexpression of both lexA and $\operatorname{rec} A$. Upregulation of another two genes tus and $y e b G$ which are related to stopping DNA replication by blocking the movement of the replication fork and assisting in SOS response, respectively, indicated a DNA damaging stimuli presented by the CFCSs components (Roecklein et al., 1991; Lomba et al., 1997). Following the gene expression results of this study, we observed the DNA damaging effect of CFCS on EHEC EDL933 genomic DNA on the agarose gel. Such an effect could be attributed to the acidic $\mathrm{pH}$ of the CFCSs, but the same outcome was observed with $\mathrm{pH}$ adjusted CFCSs. So, the DNA damaging effect is linked to the specific compounds of CFCS possibly $\mathrm{H}_{2} \mathrm{O}_{2}$ (Brudzynski et al., 2012). The residual product size of the cleaved DNA on agarose gel poses an interesting observation that requires further investigation to reveal their sequences.

Molecular chaperones are proteins that assist a wide range of other proteins and enzymes to ensure their correct tertiary and quaternary conformation and functionality in vivo (Bukau et al., 2000; Saibil, 2013). All living cells constitutively maintain an intense regulation of chaperon gene expression to maintain consistency in protein folding to cope up with any growth perturbation (Morimoto, 1998). Therefore, chaperones or heat shock proteins are always expressed but expressed differently during stress conditions. In this study, an upregulation of the chaperon gene expression (ibp $A, i b p B, c l p B, g r p E$, dnaJ, and $d n a K)$ in the presence of CFCSs was observed. Our findings in chaperon gene expression indicated stressed conditions created by CFCSs. However, as chaperones are involved in multiple complex cross-talks that are active in various conditions, further extensive analysis is needed to evaluate whether the upregulation is directed by solely CFCS-induced stress conditions.

Though evaluating the mechanism of total CFCS rather than finding out the individual metabolite responsible for exerting the antibacterial effect on EHEC is a limitation, but to our knowledge, this is the first study to address the mechanism of action of metabolites produced by probiotics against foodborne

\section{REFERENCES}

Achar, P. N., Hermetz, K., Rao, S., Apkarian, R., and Taylor, J. (2009). Microscopic studies on the Aspergillus flavus infected kernels of commercial peanuts in Georgia. Ecotoxicol. Environ. Saf. 72, 2115-2120. doi: 10.1016/j.ecoenv.2009. 04.002

Addinall, S. G., Cao, C., and Lutkenhaus, J. (1997). Temperature shift experiments with an $\mathrm{ftsZ} 84(\mathrm{Ts})$ strain reveal rapid dynamics of Fts $Z$ localization and indicate that the $\mathrm{Z}$ ring is required throughout septation and cannot reoccupy division sites once constriction has initiated. J. Bacteriol. 179, 4277-4284. doi: 10.1128/ jb.179.13.4277-4284.1997

Aditya, A., Alvarado-Martinez, Z., Nagarajan, V., Peng, M., and Biswas, D. (2019). Antagonistic effects of phenolic extracts of Chokeberry pomace on E. coli O157: $\mathrm{H} 7$ but not on probiotic and normal bacterial flora. J. Berry Res. 9, 459-472. doi: $10.3233 /$ jbr- 190383
E. coli O157: H7. Further in-depth and extensive research is needed to find out the responsible metabolites by investigating specific protein-ligand interaction through combining different computational approaches. The orchestrated effect of metabolites present in the CFCSs of probiotics on the membrane and genomic DNA of EHEC could be potentially targeted to develop a therapeutic for EHEC infections including HUS.

\section{DATA AVAILABILITY STATEMENT}

The raw data supporting the conclusions of this article will be made available by the authors, without undue reservation.

\section{AUTHOR CONTRIBUTIONS}

AA designed and performed experiments, interpreted and analyzed data, ensured the integrity of the work, and prepared and revised the manuscript. MP ensured the accuracy of the work and revised the manuscript. AY performed experiments and proofread the manuscript. DB contributed to the conception and plan of the project and ensured both the accuracy and integrity of the work and critically revised and approved the final manuscript for submission and publication. All authors contributed to the article and approved the submitted version.

\section{FUNDING}

We would like to thank USDA-NIFA for partial grant support (Exploratory Grant: 2018-67030-27426) for this study.

\section{ACKNOWLEDGMENTS}

We acknowledge the support of the Maryland NanoCenter and its AIMLab for SEM. We also thank Bioscience Cores of the University of Maryland-College Park for fluorescent microscopy. Very special gratitude to Chaitra Surugihalli, a graduate student of the University of Maryland-College Park for her help in measuring fluorescent optical density.

Arends, S. J. R., and Weiss, D. S. (2004). Inhibiting cell division in Escherichia coli has little if any effect on gene expression. J. Bacteriol. 186, 880-884. doi: 10.1128/jb.186.3.880-884.2004

Arya, S. S., Salve, A. R., and Chauhan, S. (2016). Peanuts as functional food: a review. J. Food Sci. Technol. 53, 31-41. doi: 10.1007/s13197-0152007-9

Banni, S. (2002). Conjugated linoleic acid metabolism. Curr. Opin. Lipidol. 13, 261-266.

Barnett, D., Baldo, B. A., and Howden, M. E. H. (1983). Multiplicity of allergens in peanuts. J. Allergy Clin. Immunol. 72, 61-68. doi: 10.1016/0091-6749(83) 90053-2

Bell, B. P., Griffin, P. M., Lozano, P., Christie, D. L., Kobayashi, J. M., and Tarr, P. I. (1997). Predictors of hemolytic uremic syndrome in children during a large outbreak of Escherichia coli O157:H7 infections. Pediatrics 100:E12. 
Belury, M. A. (2002). Inhibition of carcinogenesis by conjugated linoleic acid: potential mechanisms of action. J. Nutr. 132, 2995-2998. doi: 10.1093/jn/131. 10.2995

Bernet, M. F., Brassart, D., Neeser, J. R., and Servin, A. L. (1994). Lactobacillus acidophilus LA 1 binds to cultured human intestinal cell lines and inhibits cell attachment and cell invasion by enterovirulent bacteria. Gut 35, 483-489. doi: 10.1136/gut.35.4.483

Brissette, J. L., Russel, M., Weiner, L., and Model, P. (1990). Phage shock protein, a stress protein of Escherichia coli. Proc. Natl. Acad. Sci. U.S.A. 87, 862-866.

Broberg, A., Jacobsson, K., Ström, K., and Schnürer, J. (2007). Metabolite profiles of lactic acid bacteria in grass silage. Appl. Environ. Microbiol. 73, 5547-5552. doi: 10.1128/aem.02939-06

Brudzynski, K., Abubaker, K., and Miotto, D. (2012). Unraveling a mechanism of honey antibacterial action: polyphenol/H2O2-induced oxidative effect on bacterial cell growth and on DNA degradation. Food Chem. 133, 329-336. doi: 10.1016/j.foodchem.2012.01.035

Bukau, B., Deuerling, E., Pfund, C., and Craig, E. A. (2000). Getting newly synthesized proteins into shape. Cell 101, 119-122. doi: 10.1016/s00928674(00)80806-5

Callaway, T. R., Anderson, R. C., Edrington, T. S., Genovese, K. J., Harvey, R. B., Poole, T. L., et al. (2013). Advances in Microbial Food Safety: 14. Novel Methods for Pathogen Control in Livestock Pre-Harvest: an Update. Amsterdam: Elsevier.

Campoy, S., Salvador, N., Cortés, P., Erill, I., and Barbé, J. (2005). Expression of canonical SOS genes is not under LexA repression in Bdellovibrio bacteriovorus. J. Bacteriol. 187, 5367-5375. doi: 10.1128/jb.187.15.5367-5375.2005

Cardenal-Muñoz, E., and Ramos-Morales, F. (2011). Analysis of the expression, secretion and translocation of the Salmonella enterica type III secretion system effector SteA. PLoS One 6:e26930. doi: 10.1371/journal.pone.0026930

Charernjiratragul, W., Bhoopong, P., Kantachote, D., Jomduang, S., Kong-Ngoen, R., Nair, G. B., et al. (2010). Inhibitory activity of lactic acid bacteria isolated from Thai fermented food against pandemic strains of Vibrio parahaemolyticus. J. Food Saf. 30, 67-82. doi: 10.1111/j.1745-4565.2009.00190.x

Chatterjee, S. N., and Chaudhuri, K. (2012). Outer Membrane Vesicles of Bacteria. Berlin: Springer Science+Business Media.

Chomczynski, P., and Sacchi, N. (1987). Single-step method of RNA isolation by acid guanidinium thiocyanate-phenol-chloroform extraction. Anal. Biochem. 162, 156-159. doi: 10.1006/abio.1987.9999

Cimolai, N., Morrison, B. J., and Carter, J. E. (1992). Risk factors for the central nervous system manifestations of gastroenteritis-associated hemolytic-uremic syndrome. Pediatrics 90, 616-621.

Cleveland, J., Montville, T. J., Nes, I. F., and Chikindas, M. L. (2001). Bacteriocins: safe, natural antimicrobials for food preservation. Int. J. Food Microbiol. 71, 1-20. doi: 10.1016/s0168-1605(01)00560-8

Cordonnier, C., Etienne-Mesmin, L., Thévenot, J., Rougeron, A., Rénier, S., Chassaing, B., et al. (2017). Enterohemorrhagic Escherichia coli pathogenesis: role of long polar fimbriae in Peyer's patches interactions. Sci. Rep. 7:44655.

Delgado, A., Arroyo López, F. N., Brito, D., Peres, C., Fevereiro, P., and GarridoFernández, A. (2007). Optimum bacteriocin production by Lactobacillus plantarum $17.2 \mathrm{~b}$ requires absence of $\mathrm{NaCl}$ and apparently follows a mixed metabolite kinetics. J. Biotechnol. 130, 193-201. doi: 10.1016/j.jbiotec.2007. 01.041

Drexler, M., and Institute of Medicine (US), (2010). Prevention and Treatment. Washington, DC: National Academies Press.

Elderkin, S., Jones, S., Schumacher, J., Studholme, D., and Buck, M. (2002). Mechanism of action of the Escherichia coli phage shock protein PspA in repression of the AAA family transcription factor PspF. J. Mol. Biol. 320, 23-37. doi: 10.1016/s0022-2836(02)00404-7

Farkas, A., Maróti, G., Kereszt, A., and Kondorosi, É. (2017). Comparative analysis of the bacterial membrane disruption effect of two natural plant antimicrobial peptides. Front. Microbiol. 8:51. doi: 10.3389/fmicb.2017.00051

Friedberg, E. C., Walker, G. C., Siede, W., and Wood, R. D. (2005). DNA Repair and Mutagenesis. Washington, DC: American Society for Microbiology Press.

Fuller, R. (1989). Probiotics in man and animals. J. Appl. Bacteriol. 66, 365-378. doi: 10.1111/j.1365-2672.1989.tb05105.x

Gillner, D. M., Becker, D. P., and Holz, R. C. (2013). Lysine biosynthesis in bacteria: a metallodesuccinylase as a potential antimicrobial target. J. Biol. Inorg. Chem. 18, 155-163. doi: 10.1007/s00775-012-0965-1
Grosso, G., Yang, J., Marventano, S., Micek, A., Galvano, F., and Kales, S. N. (2015). Nut consumption on all-cause, cardiovascular, and cancer mortality risk: a systematic review and meta-analysis of epidemiologic studies. Am. J. Clin. Nutr. 101, 783-793. doi: 10.3945/ajcn.114.099515

Johns, C. O., and Jones, D. B. (1916). The proteins of the peanut, Arachis hypogæa I. the globulins arachin and conarachin. J. Biol. Chem. 28, 77-87.

Joly, N., Engl, C., Jovanovic, G., Huvet, M., Toni, T., Sheng, X., et al. (2010). Managing membrane stress: the phage shock protein (Psp) response, from molecular mechanisms to physiology. FEMS Microbiol. Rev. 34, 797-827. doi: 10.1111/j.1574-6976.2010.00240.x

Jonas, K. (2014). To divide or not to divide: control of the bacterial cell cycle by environmental cues. Curr. Opin. Microbiol. 18, 54-60. doi: 10.1016/j.mib.2014. 02.006

Jones, R. J., Hussein, H. M., Zagorec, M., Brightwell, G., and Tagg, J. R. (2008). Isolation of lactic acid bacteria with inhibitory activity against pathogens and spoilage organisms associated with fresh meat. Food Microbiol. 25, 228-234. doi: 10.1016/j.fm.2007.11.001

Jovanovic, G., Lloyd, L. J., Stumpf, M. P. H., Mayhew, A. J., and Buck, M. (2006). Induction and function of the phage shock protein extracytoplasmic stress response in Escherichia coli. J. Biol. Chem. 281, 21147-21161. doi: 10.1074/jbc. m602323200

Kechagia, M., Basoulis, D., Konstantopoulou, S., Dimitriadi, D., Gyftopoulou, K., Skarmoutsou, N., et al. (2013). Health benefits of probiotics: a review. ISRN Nutr. 2013:481651.

Kishino, S., Ogawa, J., Omura, Y., Matsumura, K., and Shimizu, S. (2002). Conjugated linoleic acid production from linoleic acid by lactic acid bacteria. J. Am. Oil Chem. Soc. 79, 159-163. doi: 10.1007/s11746-002-0451-4

Kreuzer, K. N. (2013). DNA damage responses in prokaryotes: regulating gene expression, modulating growth patterns, and manipulating replication forks. Cold Spring Harb. Perspect. Biol. 5:a012674. doi: 10.1101/cshperspect.a012674

Lamuel-Raventos, R. M., and Onge, M. P. S. (2017). Prebiotic nut compounds and human microbiota. Crit. Rev. Food Sci. Nutr. 57, 3154-3163. doi: 10.1080/ 10408398.2015.1096763

Lewis, K. (2019). Persister Cells and Infectious Disease. London: Springer Nature.

Livak, K. J., and Schmittgen, T. D. (2001). Analysis of relative gene expression data using real-time quantitative PCR and the 2(-Delta Delta C(T)) Method. Methods 25, 402-408. doi: 10.1006/meth.2001.1262

Llor, C., and Bjerrum, L. (2014). Antimicrobial resistance: risk associated with antibiotic overuse and initiatives to reduce the problem. Ther. Adv. Drug Saf. 5, 229-241. doi: 10.1177/2042098614554919

Lomba, M. R., Vasconcelos, A. T., Pacheco, A. B., and de Almeida, D. F. (1997). Identification of yebG as a DNA damage-inducible Escherichia coli gene. FEMS Microbiol. Lett. 156, 119-122. doi: 10.1111/j.1574-6968.1997.tb12715.x

Matsuo, Y., Miyoshi, Y., Okada, S., and Satoh, E. (2012). Receptor-like molecules on human intestinal epithelial cells interact with an adhesion factor from Lactobacillus reuteri. Biosci. Microbiota Food Health 31, 93-102. doi: 10.12938/ bmfh.31.93

Mercenier, A., Lenoir-Wrjnkoop, I., and Sanders, M. E. (2008). Physiological and functional properties of probiotics. J. Milk Sci. Biotechnol. 26, 53-57.

Mezaini, A., Chihib, N.-E., Dilmi Bouras, A., Nedjar-Arroume, N., and Hornez, J. P. (2009). Antibacterial activity of some lactic acid bacteria isolated from an algerian dairy product. J. Environ. Public Health 2009:678495.

Ming, T., Han, J., Li, Y., Lu, C., Qiu, D., Li, Y., et al. (2018). A metabolomics and proteomics study of the Lactobacillus plantarum in the grass carp fermentation. BMC Microbiol. 18:216. doi: 10.1186/s12866-018-1354-x

Morimoto, R. I. (1998). Regulation of the heat shock transcriptional response: cross talk between a family of heat shock factors, molecular chaperones, and negative regulators. Genes Dev. 12, 3788-3796. doi: 10.1101/gad.12.24.3788

Murray, M. D., and Brater, D. C. (1993). Renal toxicity of the nonsteroidal anti-inflammatory drugs. Annu. Rev. Pharmacol. Toxicol. 33, 435-465.

Nigatu, J. M., Tuji, F. A., and Tefera, A. T. (2015). Evaluation of the antagonistic effect of six mixed cultures of lactic acid bacteria, isolated from the Ethiopian fermented milk ergo, against some foodborne pathogens inoculated into the Ethiopian cottage cheese ayib. Afr. J. Microbiol. Res. 9, 1789-1797. doi: 10.5897/ ajmr2015.7504

Nonaka, G., Blankschien, M., Herman, C., Gross, C. A., and Rhodius, V. A. (2006). Regulon and promoter analysis of the E. coli heat-shock factor, $\sigma 32$, reveals a 
multifaceted cellular response to heat stress. Genes Dev. 20, 1776-1789. doi: 10.1101/gad.1428206

Ogawa, J., Matsumura, K., Kishino, S., Omura, Y., and Shimizu, S. (2001). Conjugated linoleic acid accumulation via 10-hydroxy-12-octadecaenoic acid during microaerobic transformation of linoleic acid by Lactobacillus acidophilus. Appl. Environ. Microbiol. 67, 1246-1252. doi: 10.1128/aem.67.3. 1246-1252.2001

Ouwehand, A. C., Salminen, S., and Isolauri, E. (2002). Probiotics: an overview of beneficial effects. Antonie Van Leeuwenhoek 82, 279-289. doi: 10.1007/978-94017-2029-8_18

Peng, M., and Biswas, D. (2017). Short chain and polyunsaturated fatty acids in host gut health and foodborne bacterial pathogen inhibition. Crit. Rev. Food Sci. Nutr. 57, 3987-4002. doi: 10.1080/10408398.2016.1203286

Peng, M., Bitsko, E., and Biswas, D. (2015a). Functional properties of peanut fractions on the growth of probiotics and foodborne bacterial pathogens. J. Food Sci. 80, M635-M641.

Peng, M., Reichmann, G., and Biswas, D. (2015b). Lactobacillus casei and its byproducts alter the virulence factors of foodborne bacterial pathogens. J. Funct. Foods 15, 418-428. doi: 10.1016/j.jff.2015.03.055

Peng, M., Tabashsum, Z., Patel, P., Bernhardt, C., and Biswas, D. (2018). Linoleic acids overproducing Lactobacillus casei limits growth, survival, and virulence of Salmonella typhimurium and enterohaemorrhagic Escherichia coli. Front. Microbiol. 9:2663. doi: 10.3389/fmicb.2018.02663

Pranckute, R., Kaunietis, A., Kuisienė, N., and Čitavičius, D. J. (2016). Combining prebiotics with probiotic bacteria can enhance bacterial growth and secretion of bacteriocins. Int. J. Biol. Macromol. 89, 669-676. doi: 10.1016/j.ijbiomac.2016. 05.041

Price, M. N., Deutschbauer, A. M., Skerker, J. M., Wetmore, K. M., Ruths, T., Mar, J. S., et al. (2013). Indirect and suboptimal control of gene expression is widespread in bacteria. Mol. Syst. Biol. 9:660. doi: 10.1038/msb.2013.16

Ramalingum, N., and Mahomoodally, M. F. (2014). The therapeutic potential of medicinal foods. Adv. Pharmacol. Sci. 2014:354264.

Reid, G., and McCormick, J. K. (2002). Time for probiotics. Lancet Infect. Dis. 2:459.

Ren, D., Zhu, J., Gong, S., Liu, H., and Yu, H. (2018). Antimicrobial characteristics of lactic acid bacteria isolated from homemade fermented foods. Biomed Res. Int. 2018:5416725.

Roecklein, B., Pelletier, A., and Kuempel, P. (1991). The tus gene of Escherichia coli: autoregulation, analysis of flanking sequences and identification of a complementary system in Salmonella typhimurium. Res. Microbiol. 142, 169175. doi: 10.1016/0923-2508(91)90026-7

Rurangwa, E., Laranja, J. L., Houdt, R. V., Delaedt, Y., Geraylou, Z., de Wiele, T. V., et al. (2009). Selected nondigestible carbohydrates and prebiotics support the growth of probiotic fish bacteria mono-cultures in vitro. J. Appl. Microbiol. 106, 932-940. doi: 10.1111/j.1365-2672.2008.04034.x

Saarela, M., Mogensen, G., Fondén, R., Mättö, J., and Mattila-Sandholm, T. (2000). Probiotic bacteria: safety, functional and technological properties. J. Biotechnol. 84, 197-215. doi: 10.1016/s0168-1656(00)00375-8

Saibil, H. (2013). Chaperone machines for protein folding, unfolding and disaggregation. Nat. Rev. Mol. Cell Biol. 14, 630-642. doi: 10.1038/nrm3658

Sakoh, M., Ito, K., and Akiyama, Y. (2005). Proteolytic activity of HtpX, a membrane-bound and stress-controlled protease from Escherichia coli. J. Biol. Chem. 280, 33305-33310. doi: 10.1074/jbc.m506180200

Salaheen, S., Jaiswal, E., Joo, J., Peng, M., Ho, R., OConnor, D., et al. (2016). Bioactive extracts from berry byproducts on the pathogenicity of Salmonella typhimurium. Int. J. Food Microbiol. 237, 128-135. doi: 10.1016/j.ijfoodmicro. 2016.08.027
Salminen, S. J., Gueimonde, M., and Isolauri, E. (2005). Probiotics that modify disease risk. J. Nutr. 135, 1294-1298. doi: 10.1093/jn/135.5.1294

Schnürer, J., and Magnusson, J. (2005). Antifungal lactic acid bacteria as biopreservatives. Trends Food Sci. Technol. 16, 70-78. doi: 10.1016/j.tifs.2004. 02.014

Schrezenmeir, J., and de Vrese, M. (2001). Probiotics, prebiotics, and synbioticsapproaching a definition. Am. J. Clin. Nutr. 73, 361s-364s.

Seshasayee, A. S. N., Fraser, G. M., Babu, M. M., and Luscombe, N. M. (2009). Principles of transcriptional regulation and evolution of the metabolic system in E. coli. Genome Res. 19, 79-91. doi: 10.1101/gr.079715.108

Shimohata, N., Chiba, S., Saikawa, N., Ito, K., and Akiyama, Y. (2002). The Cpx stress response system of Escherichia coli senses plasma membrane proteins and controls HtpX, a membrane protease with a cytosolic active site. Genes Cells 7 , 653-662. doi: 10.1046/j.1365-2443.2002.00554.x

Sorroche, F. G., Spesia, M. B., Zorreguieta, Á., and Giordano, W. (2012). A positive correlation between bacterial autoaggregation and biofilm formation in native Sinorhizobium meliloti isolates from Argentina. Appl. Environ. Microbiol. 78, 4092-4101. doi: 10.1128/aem.07826-11

Srivastava, D., Moumene, A., Flores-Kim, J., and Darwin, A. J. (2017). Psp stress response proteins form a complex with mislocalized secretins in the Yersinia enterocolitica cytoplasmic membrane. mBio 8:e01088-17.

Stocks, S. M. (2004). Mechanism and use of the commercially available viability stain, BacLight. Cytometry A 61, 189-195. doi: 10.1002/cyto.a.20069

Tabashsum, Z., Peng, M., Salaheen, S., Comis, C., and Biswas, D. (2018). Competitive elimination and virulence property alteration of Campylobacter jejuni by genetically engineered Lactobacillus casei. Food Control 85, 283-291. doi: 10.1016/j.foodcont.2017.10.010

Ventola, C. L. (2015). The antibiotic resistance crisis. Pharm. Ther. 40, 277-283.

Vicente, M., Rico, A. I., Martínez-Arteaga, R., and Mingorance, J. (2006). Septum enlightenment: assembly of bacterial division proteins. J. Bacteriol. 188, 19-27. doi: 10.1128/jb.188.1.19-27.2006

Vu, B., Chen, M., Crawford, R. J., and Ivanova, E. P. (2009). Bacterial extracellular polysaccharides involved in biofilm formation. Molecules 14, 2535-2554. doi: 10.3390/molecules14072535

Wall, M. E., Hlavacek, W. S., and Savageau, M. A. (2004). Design of gene circuits: lessons from bacteria. Nat. Rev. Genet. 5, 34-42. doi: 10.1038/nrg1244

Waring, M. J. (1965). Complex formation between ethidium bromide and nucleic acids. J. Mol. Biol. 13, 269-282. doi: 10.1016/s0022-2836(65)8 0096-1

Weiner, L., Brissette, J. L., and Model, P. (1991). Stress-induced expression of the Escherichia coli phage shock protein operon is dependent on sigma 54 and modulated by positive and negative feedback mechanisms. Genes Dev. 5 , 1912-1923. doi: 10.1101/gad.5.10.1912

Yoshitani, K., Hizukuri, Y., and Akiyama, Y. (2019). An in vivo protease activity assay for investigating the functions of the Escherichia coli membrane protease HtpX. FEBS Lett. 593, 842-851. doi: 10.1002/1873-3468.13368

Conflict of Interest: The authors declare that the research was conducted in the absence of any commercial or financial relationships that could be construed as a potential conflict of interest.

Copyright (๑) 2020 Aditya, Peng, Young and Biswas. This is an open-access article distributed under the terms of the Creative Commons Attribution License (CC BY). The use, distribution or reproduction in other forums is permitted, provided the original author(s) and the copyright owner(s) are credited and that the original publication in this journal is cited, in accordance with accepted academic practice. No use, distribution or reproduction is permitted which does not comply with these terms. 